\title{
THE CORE OF HERITAGE TOURISM
}

\author{
Yaniv Poria \\ Richard Butler \\ David Airey \\ University of Surrey, UK
}

\begin{abstract}
The paper challenges the idea that heritage tourism is simply represented by tourists at heritage attractions and suggests rather that perceptions more properly lie at its core. Relationships among four groups of variables (personal characteristics, site attributes, awareness, perceptions) and behavior (before, during, and after) are investigated. The results indicate that the perception of a place as part of personal heritage is associated with the visitation patterns. In particular those who view a place as bound up with their own heritage are likely to behave significantly differently from others. Understanding this is useful for the study of tourists' behavior and for the management of sites. Keywords: heritage, heritage site, heritage tourism, perception, behavior. (c) 2003 Elsevier Science Ltd. All rights reserved.

Résumé: L 'article conteste l 'idée que le tourisme patrimonial soit représenté simplement par les touristes aux sites patrimoniaux et suggère que les perceptions proviennent plutôt de son cour. One examine les relations entre quatre groupes de variables (caractéristiques personnelles, attributs du site, conscience, perceptions) et de comportements (avant, pendant et après). Les résultats indiquent que la perception d 'un endroit comme partie de 1 'héritage personnel est associée aux schémas des visites. En particulier, ceux qui considèrent que 1 'endroit est lié à leur propre héritage ont tendance à se comporter bien différemment des autres. Il serait utile de comprendre cela afin de mieux étudier le comportement des touristes et de bien gérer les sites. Mots-clés: patrimoine, site patrimonial, tourisme patrimonial, perception, comportement. (C) 2003 Elsevier Science Ltd. All rights reserved.
\end{abstract}

\section{INTRODUCTION}

This paper investigates the links between tourists and the heritage presented at destinations, in order to understand better what is termed heritage tourism. The research draws upon a bigger study, which investigated a number of locations. This paper deals with one of these, with the specific purpose of investigating whether the relationship between the tourists and their perceptions is linked to their visitation patterns. It argues that the understanding and management of heritage tourism as a social phenomenon should not be based solely on an arbitrary factor: the presence of tourists. It is suggested that elements more sub-

Yaniv Poria is at the Department of Hotel and Tourism Management, Ben Gurion University of the Negev and Dick Butler and David Airey are professors in the School of Management at the University of Surrey (Guildford GU2 7XH, UK. Email <yporia@bgumail.bgu.ac.il>) Poria's research interests are the relationships among tourist characteristics, site attributes, tourism perceptions, and visitation patterns. Butler's areas include destination development, sustainability, and impact assessment. Airey's cover tourism education, policy, and development. 
jective in nature and relating to the actual relationship between the space and the individual lie at the core of this phenomenon. The research presented challenges the perception that all those who visit a place come only to "gaze", be educated or to enjoy themselves. For some, it is argued this is an emotional experience, that people come to "feel" rather than to "gaze" (Urry 1990).

\section{CLARIFYING THE CORE OF HERITAGE TOURISM}

Heritage, "the 'buzz' word of the 1990s" (Palmer 1999:315), is regarded as one of the most significant and fastest growing components of tourism (Alzua, O'Leary and Morrison 1998; Herbert 1995). It is referred to as something which needs to be managed (Cheung 1999) and marketed (Bennett 1995) differently. The subject is of increasing interest from a range of disciplines and its study is perceived as useful for understanding social behavior of individuals and society as a whole (Hewison 1987; Nuryanti 1996). Research has focused on the growing "heritage industry" (Conlin 2001; Hewison 1987) where researchers often differentiate between cultural (Richards 1996), natural (Hall 2000), and built (Laws 1998) elements. This paper focuses upon what is generally called cultural heritage, but for convenience the term heritage is used throughout.

The literature commonly investigates and clarifies elements associated with the supply of heritage and its management (Crang 1999; Halewood and Hannam 2001; Garrod and Fyall 2000). Less interest and attention has been paid to the demand component and even less to the relationship between the two. Of the literature about demand, much is concerned with motivation (Swarbrooke 1994) and market segments (Richards 1996). Few studies explore the relationship between these and the core of site attributes, which is believed to be essential for understanding heritage tourism as a social phenomenon. Clarification of this relationship could provide researchers with the theoretical background necessary for a more meaningful understanding.

Earlier work in this field in Ghana (Bruner 1995), and at the Irish National Heritage Park (Johnson 1999) refers to perceptions as a factor relevant in understanding behavior. Cheung (1999) indicates that a location (Ping Shan Heritage Trail) can have different meanings for different people. Fawcett and Cormack (2000) suggest that, in the context of the presentation of artifacts associated with literature (authors and/or their stories), the actual perception of something as authentic may be influenced by the understanding of what is "real" and "authentic". Gruffudd, Herbert and Piccini (1999) believe that what is presented stimulates thought and notions based on the individual's background. Michael (2002) asserts that heritage tourism should not be viewed in terms of arbitrary issues, but should take into consideration sociopsychological needs. Another study of relevance here concerns residents' attitudes. Uriely, Israeli and Reichel (2002), taking into account local people's religious affiliations, argue that the relationship between the local residents and the heritage presented can influence the locals' attitudes towards development (in Nazareth, in the case of 
their study). Geographic and psychological literature suggests that in order to understand individual behavior in a specific space, it is necessary to reveal certain aspects of the links between the individual and that space (Zube 1987; Zube, Sell and Taylor 1982). Although all these studies used perception, this concept was not explored in relation to the specific issue under scrutiny here. Exactly what perception refers to remains open, and its relation to personal heritage was not investigated. Nevertheless, the literature suggests that some links are relevant to the understanding and this relationship is examined in this paper.

In fact the literature contains two main approaches to the precise phenomenon under study. The first and most common is to regard it as tourism in places categorized as heritage or historic places. An example of this approach is illustrated in Seale's description "the visitors to heritage areas/sites" (1996:486) or Laws' arbitrary classification of those visiting castles as heritage tourists (1998). Another example is Halewood and Hannam, who consider museums that "give information about the Viking period" (2001:569) to be part of heritage tourism, based purely on the fact that they present history. This approach suggests that the actual presence of tourists is sufficient. The second approach emphasizes that the contents of a place are linked to the phenomenon, as illustrated by Strauss and Lord. In their opening sentence, they indicate "history is a popular theme for recreational travel" and they refer to activities in relation to the artifacts presented (2001:199). This approach emphasizes that the history featured is part of the experience and partially links it with motivations for the trip. However, neither of these two approaches focuses on the core of the issue explored in this paper as its research problem: the relationship between perceptions and behavior. In other words, is it possible to distinguish a separate category of people by their behavior, and can this be linked to their perceptions related to their own heritage?

The approach taken in this research is closely related to other growing areas of investigation, notably authenticity and the nature of reality and objectivity (Morris 1988). This is in line with the view of Crang that subjects "can never experience the authentic but always end up faced with markers of that experience rather than the experience itself" (1996:416). It also accords with claims that there is no such concept as one history and any presentation of it in any context is to some extent subjective (Crang 1999; Sivan 1997). Following this thinking, the paper seeks to identify heritage tourism as a phenomenon related to demand rather than to the artifacts presented. For this reason, no attempt is made to discuss the nature of the heritage presented nor whether the relationships are real or objective. This of course is different from other approaches as well as international conventions that identify heritage from the point of view of supply. However, the approach taken here, which represents a shift in perspective, is important in helping to understand this phenomenon and identify other subgroups. If such relationships are found, it may be that other subgroups would be better defined in terms of the interplay among a site, its tourists, and their subjective perceptions (Poria, Butler and Airey 2001b). 


\section{Study Methods}

To address the research problem, it was necessary to unravel the relationship between, on the one hand, the tourists and their perceptions and, on the other, their behavior. Four components were examined as the explained variables: personal characteristics, the site attributes, awareness, and perception. It is suggested that the relationship among these factors is crucial, especially when what is presented can be linked to the individuals in a way that is intimate to their identity. The statement of Swarbrooke that "the reality of a product or experience is probably less important .... than the consumer's perception of it" (1996:A69) and the question of awareness were explored via a set of questions (Clements and Josiam 1995). In general, in order for something to be interpreted, and to be perceived as having meaning, an individual needs to be aware of it (Solomon, Bamossy and Askegaard 1999). With this in mind, it was necessary to clarify whether tourists were aware of the site and its characteristics (Bockstein, Bennett and Uken 1991).

The outcome variable was the visitation patterns. To identify any links with the explanatory variables, it was decided to study behavior: before, during, and after the visit. Those before included motivations and previous visits. Concentration on motivations was due to the crucial importance of this variable in understanding behavior (Balogulu and Uysal 1996; Crompton 1979). During the visit, the research concentrated on actions (such as purchasing souvenirs and length of stay), and perceptions. Satisfaction was explored as it is associated with expectations as well as the actual experience. Differences in the level of satisfaction may also be useful in distinguishing between different types of people. Behavior afterwards included the intentions to revisit (whether or not an entrance fee is charged), as well as willingness to recommend to others. As the literature suggests, these two patterns of behavior are associated with consumer perceptions and could provide a basis for understanding (Kozak 1999; Murphy 2001).

One of the key attributes of the study location was that it should present a diversity of respondents. In this context, Israel is a highly suitable location in that it contains, in a relatively small area, many places that would seem to relate differently to different individuals (Akhtar 2000; Schiller 1992). The country covers most of the biblical Holy Land and some locations associated with Islam. Israel is also tied strongly to Jewish communities and Zionism around the world (Giddens 1998). It was recognized from the beginning that the choice of Israel would result in investigating places associated with the Bible, as well as with the history of the state of Israel. While the study as a whole explored a number of different locations (Poria 2001a), this paper presents the findings pertaining solely to the Wailing Wall.

The Wailing Wall is in fact a very small area. Its actual length, accessible to the public, is about 60 meters. The Wailing Wall (Ha-Kotel HaMa'aravi in Hebrew, or the Western Wall) is the most important religious location for Jews and also has historic significance as it is believed to be part of the original Temple. In addition, it is associated 
with Israel's victory in the Six-Day War (1967), which for Zionists symbolizes the existence of an independent Jewish state (Aner, Ben-Dov and Naor 1981). The Wailing Wall is also relevant to Christians on religious grounds, as Jesus stood there and prophesized the downfall of the Temple and criticized the way it was run and how religion was being practiced (Schiller 1992). The space is highly appropriate for the purposes of this research due to its other attributes: it is located in proximity to other attractions visited by different groups (the Holy Sepulchre, Via Dolorosa, Yad Vashem); there is no other attraction adjacent to the Wall itself, which might have an influence; entrance is open to all (unlike others with a religious orientation in Jerusalem such as Al-Haram al-Sharif); and there is no entrance fee. Due to this combination of factors, the Wailing Wall is visited by a variety of tourists who may approach its history in different ways. It is this variety that provides a good basis for exploring the relationships that are at the heart of this study.

The research instrument was a structured questionnaire implemented through face-to- face interviews at Ben-Gurion airport on departure from Israel. Eysenck (1998) argues that a vacation provides an episodic memory containing personal experiences associated with a particular time and place, and thus on departure information can be provided about the whole experience. Further, at this point memories were fresh; and since most people visiting Israel leave from BenGurion airport, this was a good location to conduct the survey (Israel Ministry of Tourism 1996).

The fieldwork needed a period when there would be a maximum mix of tourists in Israel, thus avoiding specific religious holidays and a Papal visit which took place in 2000. The objective of the sampling strategy chosen was not to achieve a representative sample, but to include a diversity that would be able to provide data relevant to the research investigation. This diversity among personal characteristics as well as among perceptions is essential for the purpose of this research. The actual population was departing international tourists who were able to speak and understand English and were above 15 years old (Apter, Hatab, Tyano and Weizinan (1998) consider cognitive abilities stable at this age). The reason for only sampling non-residents was the greater diversity among them than among the local population. Every $n$th individual who was in the duty-free area was approached (the $n$th value was determined by factors such as the number of interviewers and the number of flights departing at a certain time period). Before inclusion in the sample, the interviewees were asked to confirm whether or not they were on a tourist trip. Only those answering in the affirmative were included. The interviews were conducted by five students selected on academic criteria and after interviews with one of the authors. They were not told about the specific objectives of the research in order to reduce the likelihood that they might lead the interviewees to certain answers.

A pilot survey took place in December 1999 and the main data collection between mid-April and mid-May 2000. The interviews were carried out at day and night times, both on weekdays and weekends. The 
findings presented in this study are based on descriptions of association as well as differences among groups based on averages. The associations reported are based on a significance level of 0.05 . For differences among more than two groups, a Scheffe test was used with a level of significance of 0.01 , as this is stricter than the more commonly used Tucky test. As the use of parametric and non-parametric tests is one of the "unresolved issues in data analysis" (Bryman and Cramer 1996:117), it was decided to report only findings in which significant results were found from both techniques. For convenience, the results are presented based on the use of parametric tests only.

\section{Study Findings}

The whole sample was composed of 398 participants $(38.2 \%$ female and $61.8 \%$ male). The unequal ratio of male to female could be due to business tourists of whom more are normally men than women. In this sample, $304(92.7 \%)$ went to the Wailing Wall. Of these $30.8 \%$ were Jewish, $62.6 \%$ Christian, and $8.6 \%$ of other religions. Participants were asked for the strength of their religious belief based on a scale between 0 to 6 ( 0 representing "I am not religious at all" and 6 "I consider myself very religious"). A One Way Anova test was conducted which illustrated significant differences. Scheffe tests indicated that the differences between Jews (3.28) and Christians (3.92) was found to be significant $(P=0.046)$. The five most common places of residence (of 42 listed) were: the United States $(33.6 \%)$, the United Kingdom (21.3\%), France $(7.8 \%)$, Germany $(5.5 \%)$, and South Africa $(3.5 \%)$. Almost half $(48.7 \%)$ traveled with a family member, $36.5 \%$ with friends. Of those with someone else, $8.2 \%$ were with one or two children under 12 years old. Among those who estimated their yearly income in US Dollars the mode was $\$ 25,001-50,000$. Some $66.8 \%$ of the sample had undergraduate or graduate education. With respect to age, the mode was 20-29 years $(26.1 \%)$ and the median $40-49$ years.

The main factor in explaining differences in visitation patterns to the Wailing Wall was found to be perceptions of the site in relation to personal heritage, and this is the main finding presented in this paper. The differences in the perceptions (in comparison to other explanatory variables explored) lead to clear distinctions in each of the subgroups and to an understanding of behavior.

Before proceeding to consider the differences, it is useful to outline the actual perceptions expressed by respondents on a seven-point scale. The key finding from this is that most of the responses were concentrated at the two ends of the scale: the site is absolutely not perceived as part of the individual's heritage $(26.3 \%)$ or is absolutely so perceived $(28 \%)$. This bipolar finding was also supported in the answers to five further questions.

Turning to the visitation patterns, these were analyzed against the perception of the Wailing Wall. Clear differences and relationships were found in the periods before, during, and after the visit. In connection with the period before, the respondents were asked to comment on statements dealing with their motivations. These statements were 
based on motivating factors, such as desire for emotional involvement, education, enjoyment, and relaxation. Clear patterns were found in the levels of perceptions. For example, those who visited because they wanted to be emotionally involved were very likely to perceive the place as part of their own heritage. Less clear associations were found with a second group of motivations relating to the history presented (for example, "you visited because you wanted to learn"). No associations were found with reasons not linked to the history or heritage (for example, "you visited because there was no admission fee"). Another aspect that was subject to investigation was level of intention to revisit. The results indicate that those who considered the place as "absolutely part of their heritage" were significantly different from all other groups in that they were more likely to revisit. In other words, frequency is only related to the strongest perception of the site as a part of the tourists' heritage. A likely explanation for this is that this group will be interested in visiting more than once because of the emotional experience involved.

Questions were also asked about behavior during the visit. A pattern was found in relation to length of stay. Those who saw the Wailing Wall as part of their heritage were likely to stay longer than those who did not. An explanation may be different behaviors (such as wanting to write a note or to pray) which will lead to more time being spent there. Another difference is linked to the interpretation methods used. No formal interpretive guidance is on offer and participants were asked if they used any other methods (personal guide, guidebooks, etc.). Among those who viewed the Wailing Wall as part of their own heritage, only $31.8 \%$ used interpretation methods. The figure for those who absolutely did not do so was $62.5 \%$. This may be because the former are more aware of the history, or they may feel less need to learn (particularly if they had visited in the past). Differences were found also in levels of satisfaction. In these there was a positive association (Pearson correlation $=0.361, P=0.000$ ). In other words, those who saw the place as part of their own heritage gained more satisfaction than others. The strength of this association is remarkable given the low spread of responses found in consumer satisfaction research in general (Peterson and Wilson 1992). The average level of satisfaction was 5 (on a scale where 0 indicates "totally unsatisfied" and 6 indicates "totally satisfied"). The group that did not consider the Wailing Wall as part of their own background estimated their level of satisfaction as 4.6, while those who did, estimated it as 5.64.

Four questions were asked about perception of the visit, using a 0 to 6 scale ( 0 representing "I completely disagree" and 6 "I completely agree"). These were analyzed against the respondents' perceptions of the place, also on a seven-point scale ( 0 representing "this is absolutely not part of my own heritage" and 6 "this is absolutely part of my own heritage"). The mean scores for the significant differences are based on a Scheffe test (Table 1). These are presented in groups according to the perception of the site.

It is notable that diverse views about the Wailing Wall did not lead to differences in the extent to which the experience was thought to 
contribute to education. In the context of the other three questions, the views did lead to significant differences. It is clear, for example, that those with a close connection were emotionally moved to a far greater extent than those for whom this was absolutely not the case (5.070 versus 2.725). The coherency in the answers to the last three questions presented in the table can be explained by the fact each reflects the relationship between the individual and the heritage presented. Another interesting pattern is that those who saw the place as "absolutely part of my heritage" were in nearly all cases significantly distinct from others. The number of differences presented, especially in the context of the third statement, suggests that there is an association between such a view and the perception of the visit. The linear associations suggest both modest and relatively high positive relationships (Table 2). It appears that the more the tourists consider the Wailing Wall as part of their heritage, the more they regard it as an emotional experience. The differences described here suggest that

Table 1. Perception of Site and Perception of Visit $(N=304)$

\begin{tabular}{|c|c|c|c|c|c|}
\hline \multirow[t]{2}{*}{ Perception of Visit } & \multicolumn{5}{|c|}{ Perception of the Site } \\
\hline & Group I & Mean & Group II & Mean & Sig. \\
\hline $\begin{array}{l}\text { The visit to the site } \\
\text { contributed to your } \\
\text { education }\end{array}$ & \multicolumn{5}{|c|}{ No significant difference at 0.1 (Scheffe test) } \\
\hline \multirow{5}{*}{$\begin{array}{l}\text { The visit to the site } \\
\text { moved you emotionally }\end{array}$} & 6 & 5.070 & 0 & 2.725 & 0.000 \\
\hline & 6 & 5.070 & 1 & 3.222 & 0.017 \\
\hline & 6 & 5.070 & 2 & 3.700 & 0.047 \\
\hline & 6 & 5.070 & 3 & 3.343 & 0.002 \\
\hline & 5 & 4.310 & 0 & 2.725 & 0.012 \\
\hline \multirow{9}{*}{$\begin{array}{l}\text { During the visit you felt } \\
\text { that part of your own } \\
\text { heritage was displayed }\end{array}$} & 6 & 4.894 & 0 & 0.687 & 0.000 \\
\hline & 6 & 4.894 & 1 & 1.722 & 0.000 \\
\hline & 6 & 4.894 & 2 & 1.800 & 0.000 \\
\hline & 6 & 4.894 & 3 & 2.218 & 0.000 \\
\hline & 6 & 4.894 & 4 & 3.400 & 0.018 \\
\hline & 6 & 4.894 & 5 & 3.310 & 0.010 \\
\hline & 5 & 3.310 & 0 & 0.687 & 0.000 \\
\hline & 4 & 3.400 & 0 & 0.687 & 0.000 \\
\hline & 4 & 3.400 & 2 & 1.722 & 0.06 \\
\hline \multirow{7}{*}{$\begin{array}{l}\text { The visit to the site made } \\
\text { you feel proud }\end{array}$} & 6 & 4.411 & 0 & 1.037 & 0.000 \\
\hline & 6 & 4.411 & 1 & 1.333 & 0.000 \\
\hline & 6 & 4.411 & 2 & 1.566 & 0.000 \\
\hline & 6 & 4.411 & 3 & 1.687 & 0.000 \\
\hline & 6 & 4.411 & 4 & 2.000 & 0.000 \\
\hline & 6 & 4.411 & 5 & 2.724 & 0.017 \\
\hline & 5 & 2.724 & 0 & 1.037 & 0.019 \\
\hline
\end{tabular}


those visiting are being exposed to different experiences, based on the relationship between the site attributes and themselves.

Participants were asked four questions about their potential behavior. The first two dealt with intentions to revisit and to do so if there was an entrance fee. The other two questions were concerned with intentions to recommend to friends, both with and without an entrance fee. Significant differences were found in all the questions, but those with strong perceptions that it is absolutely part of their heritage were more likely to revisit (Table 3). In the context of the first and the second questions, there were more significant differences than with the third and fourth questions. This is likely to reflect the fact that respondents have a greater level of certainty when referring to themselves than when speaking for their friends (third and fourth questions). This assumption is based on comments provided in the context of this question by the interviewees. Participants mentioned that perception and personal characteristics of their friends would be something which would influence the answers given.

Additional analyses were examined to identify further relationships between the concepts explored, revealing patterns between such elements as religious affiliation and strength of religious belief. However, these were weaker than the perceptions in relation to personal heritage and, as such, are not reported here. From a theoretical perspective, it is argued that the association found between visitation patterns and personal characteristics is due to perceptions of the site in relation to respondents' own heritage and not the other way round. For example, particular tourists do not behave in the way they do because they belong to a certain religion but because of their views about the site. In this study, although personal characteristics are associated with such patterns, they are not the reason for them. It is suggested that in places where religion is not central, the actual perception could be associated with other personal characteristics, but a real understanding of the visitation patterns is rooted in the link between individuals and their heritage. This information has practical implications, as the tourists can be segmented based on their perceptions and can be identified relatively easily based on their personal charac-

Table 2. Linear Association between Sites and Visit Perceptions ( $N=304)$

\begin{tabular}{lcclc}
\hline Perception of Visit & $\begin{array}{l}\text { Pearson } \\
\text { Correlation }\end{array}$ & Sig. & $\begin{array}{l}\text { Coefficient } \\
\text { Correlation }\end{array}$ & Sig. \\
\hline $\begin{array}{l}\text { The visit to the site contributed to your } \\
\text { education }\end{array}$ & -0.051 & 0.000 & 0.007 & 0.000 \\
$\begin{array}{l}\text { The visit to the site moved you } \\
\text { emotionally }\end{array}$ & 0.441 & 0.000 & 0.460 & 0.000 \\
$\begin{array}{l}\text { During the visit you felt that part of } \\
\text { your heritage was displayed }\end{array}$ & 0.667 & 0.000 & 0.670 & 0.000 \\
$\begin{array}{l}\text { The visit to the site made you feel } \\
\text { proud }\end{array}$ & 0.528 & 0.000 & 0.543 & 0.000 \\
\hline
\end{tabular}


teristics. This may be useful for issues linked to the operational management as well as the marketing of places.

\section{CONCLUSION}

The results of this study indicate clearly that motivations, (potential) behavior, and perceptions are all linked to perceptions of the site. These relationships are at the core of this research. It is suggested that those who perceive a site as a part of their personal heritage are the basis of the phenomenon called heritage tourism, and they are distinguished from others by their behavior. It follows that "heritage tourism" as explored here should not include those who are visiting a place "just because it is there", nor those who are primarily motivated by a wish to learn. Based on this study such tourism is not simply being in spaces which are declared by "experts" or other stakeholders to be "heritage sites". Instead, it is suggested that a definition of this type of tourism can be: "a subgroup, in which the main motivation for visiting

Table 3. Perception of Site and Potential Behavior $(N=304)$

\begin{tabular}{|c|c|c|c|c|c|}
\hline \multirow[t]{2}{*}{ Potential Behavior } & \multicolumn{5}{|c|}{ Perception of Site } \\
\hline & Group I & Mean & Group II & Mean & Sig. \\
\hline \multirow{8}{*}{$\begin{array}{l}\text { If you visit Israel in the } \\
\text { future you will revisit the } \\
\text { site }\end{array}$} & 6 & 5.800 & 0 & 3.950 & 0.000 \\
\hline & 6 & 5.800 & 1 & 4.277 & 0.041 \\
\hline & 6 & 5.800 & 2 & 3.733 & 0.000 \\
\hline & 6 & 5.800 & 3 & 4.406 & 0.009 \\
\hline & 5 & 5.241 & 0 & 3.950 & 0.035 \\
\hline & 5 & 5.241 & 2 & 3.733 & 0.047 \\
\hline & 4 & 5.533 & 0 & 3.950 & 0.002 \\
\hline & 4 & 5.533 & 2 & 3.733 & 0.005 \\
\hline \multirow{8}{*}{$\begin{array}{l}\text { You would visit the site even } \\
\text { if you had to pay an } \\
\text { entrance fee }\end{array}$} & 6 & 5.411 & 0 & 3.675 & 0.000 \\
\hline & 6 & 5.411 & 1 & 3.666 & 0.038 \\
\hline & 6 & 5.411 & 2 & 3.400 & 0.000 \\
\hline & 6 & 5.411 & 3 & 4.000 & 0.034 \\
\hline & 5 & 5.034 & 0 & 3.675 & 0.071 \\
\hline & 5 & 5.034 & 2 & 3.400 & 0.071 \\
\hline & 4 & 5.133 & 0 & 3.675 & 0.034 \\
\hline & 4 & 5.133 & 2 & 3.400 & 0.039 \\
\hline \multicolumn{2}{|l|}{$\begin{array}{l}\text { You would recommend your } 6 \\
\text { friends to visit the site if } \\
\text { they visit Israel }\end{array}$} & 5.764 & 0 & 5.237 & 0.088 \\
\hline \multicolumn{2}{|l|}{$\begin{array}{l}\text { You would recommend your } 6 \\
\text { friends to visit the site even } \\
\text { if they had to pay an } \\
\text { entrance fee }\end{array}$} & 5.494 & 0 & 4.762 & 0.060 \\
\hline
\end{tabular}


is based on the characteristics of the place according to the tourists' perception of their own heritage".

This contrasts with the existing approach of "tourism centered on what we have inherited, which can mean anything from historic buildings, to art works, to beautiful scenery" (Yale 1997:32). The differences between the two definitions are presented in Figure 1. The existing approach includes all who visit (Group I, II, III, IV). The approach in this research is to include only those in group IV. Although this reduces the scale, it leads to a better understanding (Poria, Butler and Airey 2001a), by helping researchers to differentiate between this and other groups. It also minimizes the line of thought that heritage tourism "can be rather a heterogeneous phenomenon" (Balcar and Pearce 1996:211) and prevents the rather haphazard classification of things and elements as "heritage" because people are not quite sure exactly what this title covers (Glen 1991).

At this stage it is important to emphasize that, although this study identified differences among those visiting, it is not argued that any of the groups have or do not have their own valid needs and expectations. Further, no attempt is made to suggest that an attraction can be a "satisfying tourism experience only to tourists who consider it to be

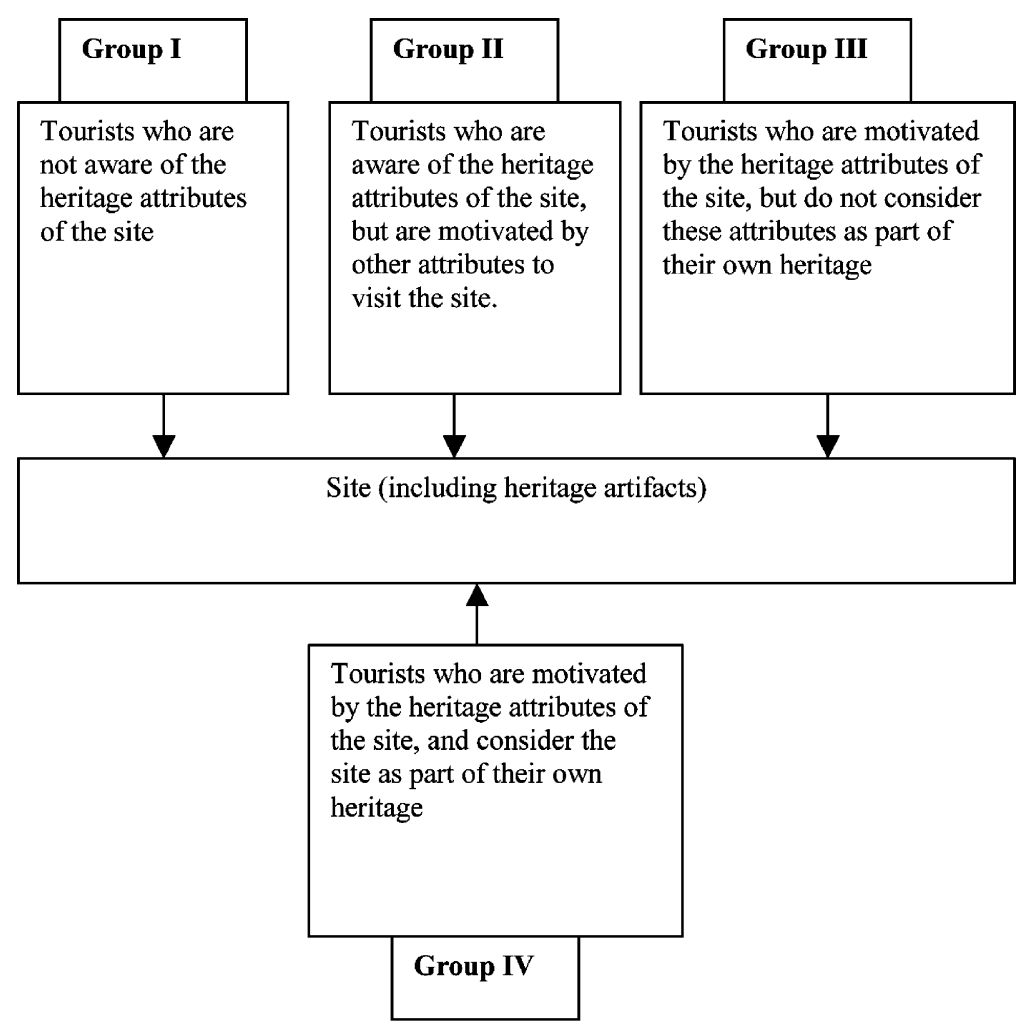

Figure 1. Segmentation of Tourists Visiting a Heritage Site 
part of their own heritage" (Garrod and Fyall 2001:1051). Nevertheless, it is argued that such groups may be different in various ways, and those who manage sites could usefully be aware that there are differences between heritage tourists and tourists at heritage places. It is important to understand that environments in which heritage is presented are places which "function not only to draw tourists...from those wishing to experience the past, but also to provide a setting for entertainment, relaxation, or shopping" (Waitt 2000:836). For some, such an attraction is actually a space to which they relate on a personal level and this differentiates them from others who come to "gaze".

This study supports the literature which suggests that understanding behavior must include understanding the relationship between individuals and the artifact or space (Boniface and Fowler 1993; Timothy 1997). The principal conclusion of the research is that heritage tourism stems from the relationship between the supply and the demand. It is not so much the attributes themselves, but the perceptions of them which is critical.

As in all research, this study has a number of limitations. Prominent among these is the limited number of locations used. An attempt to deal with this was made by ensuring a diversity of tourists, but it is recognized that a future study could improve this by including a greater diversity of sites. Other potential limitations are associated with the actual location of the survey. The fieldwork in this case was carried out in a place strongly associated with the Holy Books and the Jewish faith. As a result, this study was related to religion. It can be argued that this limitation could apply in many other circumstances. For example, if the sites investigated were in England, the heritage explored would most likely be related to a particular type of tourist and associated with a sense of Englishness. One way to overcome this limitation would be to select a wider range from more than one country.

In order to confirm the main findings and to provide a better basis for generalization, it would have been useful to test this approach in different kinds of locations. Examples could be "global must see" attractions that present historic features (such as the Acropolis, the Pyramids, and the Great Wall of China). Some perceive them as part of their heritage, some as historic sites with a high level of awareness of their history, while others may have a low level of awareness of their historic attributes. Findings from such research could sharpen the understanding of the relationship presented here.

The study supports the idea that visitation patterns have to do with participants' personal characteristics, their views, and the meanings they attach to different spaces. This suggests that a reflection about the tourists' characteristics could be made in reverse. Research could be conducted on the level of the individual and the level of societies, and could involve, for example, identifying groups and changes over time by investigating behavior patterns. A possible area to conduct such research could be a former conflict zone. For example, one could examine whether Turks who go to Turkish-Greek conflict areas (such 
as Cyprus) have different attitudes towards this history from those who do not do so.

More research is also in order about the perceptions of the experience (Poria, Butler and Airey 2002). This research found that some people who perceived a site as part of their own background were motivated by a feeling of obligation. It may be useful to explore whether or not they identify themselves as tourists despite this sense of obligation. In such a situation, the question is whether they view this as a tourist experience. This may clarify whether they are participating in a social obligation rather than a leisure experience.

The research contributes to the tourism literature by suggesting that some subgroups could be reconsidered and challenged based on the relationships between perceptions and behavior (Poria et al 2001b). This suggests that other named subgroups may not exist as unique and separate. For example, is there a real substantial difference between mountain tourism (East 1996), rural tourism (Kastenholz, Duane and Gordon 1999), or farm tourism (Clarke 1999)? This study argues that there should be a strong theoretical background for establishing subgroups, rather than just the presence of people in certain spaces, involvement in a certain activity, or common sociodemographic characteristics (Poria et al 2001b). Such classifications may be useful for marketing purposes; but, at the same time, they may lead to confusion in the theoretical understanding by highlighting relationships that may not be at the core of the behavior. Investigating and attempting to clarify such subgroups would lead to a better understanding. This also supports the line of thought that the clarification of their experience should be " 'grounded' in the realities that tourists themselves describe" (Prentice, Witt and Hamer 1996:2).

The exploration as presented here can be helpful for the management of places. As suggested, these have different meanings for different people. Understanding the tourists' profiles in relation to what is presented should lead to better management (Poria et al 2001a). The recognition and the identification of these differences can lead to managers making changes to the marketing process, the pricing system, and the interpretation provided (Poria 2001b, 2001c). Marketing research (Kotler, Bowen and Mak 1999; Teo and Yeoh 1997) suggests that these differences should have implications for the marketing process in general and for advertising in particular. As suggested in the present study, differences in perceptions in relation to personal heritage were linked to motivation. Hence those responsible for such places need to be aware of two markets: those who come to see historic artifacts to be educated or for enjoyment (well-known motivations for visiting, Crang 1996), and those who come to be emotionally involved in an experience. This information could have implications in advertising, especially if the relationship between tourists and that which is wanted is associated with personal characteristics. For example, brochures are commonly available in different languages, but the context is the same in each translation. In certain attractions, there may be a place for providing different interpretations linked to perceptions and expectations. 
In summary, this research contributes in three important ways to the body of theory. First, it suggests a new working definition for possible use by other researchers, emphasizing the relationships between perception of a site and its heritage attributes. Second, it argues that there are differences between tourists based upon their perceptions and that these lead to differences in behavior. Third, the research identifies the obligatory nature of some tourism. This makes a contribution to the theoretical background in that it provides a distinction between the individual's view of their experience as a recreation/non-recreation activity conducted in a leisure/non-leisure time frame. This may prove to be helpful to the development of theory and relationships with disciplines such as leisure, recreation, geography, and psychology. $\mathbf{A}$

\section{REFERENCES}

Akhtar, S.

2000 Christians, Muslims, Jews Living in Disharmony. The Times Higher 424:22-23.

Alzua, A., J. O'Leary, and A. Morrison

1998 Cultural and Heritage Tourism: Identifying Niches for International Travelers. The Journal of Travel and Tourism Studies 9(2):2-13.

Aner, Z., M. Ben-Dov, and M. Naor

1981 The Western Wall (in Hebrew). Givataim: Ministry of Defence.

Apter, A., J. Hatab, S. Tyano, and A. Weizinan

1998 Child and Adolescent Psychology (in Hebrew). Tel-Aviv: Dyonon Publishing.

Balcar, M., and D. Pearce

1996 Heritage Tourism on the West Coast of New Zealand. Tourism Management 17:203-212.

Balogulu, S., and M. Uysal

1996 Market Segments of Push and Pull Motivations: A Canonical Correlation Approach. International Journal of Contemporary Hospitality Management 8:32-38.

Bennett, M.

1995 Heritage Marketing: The Role of Information Technology. Journal of Vacation Marketing 3:272-280.

Bockstein, M., A. Bennett, and E. Uken

1991 How Well Tourists Know their Own Attractions. Annals of Tourism Research 18:504-508.

Boniface, P., and P. Fowler

1993 Heritage and Tourism in "The Global Village". London: Routledge.

Bruner, E.

1995 Tourism in Ghana: The Representation of Slavery and The Return of the Black Diaspora. American Anthropologist 98:290-304.

Bryman, A., and D. Cramer

1996 Quantitative Data Analysis with SPSS Release 8 for Windows: A Guide for Social Scientists. London: Routledge.

Cheung, S.

1999 The Meanings of a Heritage Trail in Hong Kong. Annals of Tourism Research 26:570-588.

Clarke, J.

1999 Marketing Structures for Farm Tourism: Beyond the Individual Provider of Rural Tourism. Journal of Sustainable Tourism 7:26-47.

Clements, C., and B. Josiam

1995 Role of Involvement in the Travel Decision. Journal of Vacation Marketing 1:337-348.

Conlin, J.

2001 The Art of Dining. The Times (August 13):52-53. 
Crang, M.

1996 Magic Kingdom or a Quixotic Quest for Authenticity? Annals of Tourism Research 23:415-431.

1999 Nation, Region and Homeland: History and Tradition in Dalarna, Sweden. Ecumene 6:447-470.

Crompton, J.

1979 Motivations for Pleasure Vacation. Annals of Tourism Research 6:408424.

East, P.

1996 Himalayan Tourism: Working Out Ways Forward. Journal of Sustainable Tourism 5:333-336.

Eysenck, M.

1998 Memory. In Psychology: An Integrated Approach, M. Eysenek, ed., pp. 167-204. Essex: Longman.

Fawcett, C., and P. Cormack

2000 Guarding Authenticity at Literary Tourism Sites. Annals of Tourism Research 28:686-704.

Garrod, B., and A. Fyall

2000 Managing Heritage Tourism. Annals of Tourism Research 27:682-708.

2001 Heritage Tourism: A Question of Definition. Annals of Tourism Research 28:682-708.

Giddens, A.

1998 Sociology. Cambridge: Polity.

Glen, M.

1991 If in Doubt Call it Heritage? In Tourism Resources: Issues, Planning and Development, D. McDowell and D. Leslie, eds., pp. 73-85. Jordanstown: University of Ulster.

Gruffudd, P., D. Herbert, and A. Piccini

1999 "Good to think": Social Constructions of Celtic Heritage in Wales. Environment and Planning D: Society and Space 17:705-721.

Halewood, C., and K. Hannam

2001 Viking Heritage Tourism: Authenticity and Commodification. Annals of Tourism Research 28:565-580.

Hall, C.

2000 Tourism and The Establishment of National Parks in Australia. In Tourism and National Parks, R. Butler and S. Boyd, eds., pp. 29-38. Chichester: Wiley.

Herbert, D.

1995 Heritage Places, Leisure and Tourism. In Heritage, Tourism and Society, D. Herbert, ed., pp. 1-20. New York: Mansell.

Hewison, R.

1987 The Heritage Industry: Britain in a Climate of Decline. London: Methuen.

Israel Ministry of Tourism

1996 Tourist Survey. Jerusalem: Israel Ministry of Tourism.

Johnson, N.

1999 Framing the Past: Time, Space and The Politics of Heritage Tourism in Ireland. Political Geography 18:187-207.

Kastenholz, E., D. Duane, and P. Gordon

1999 Segmenting Tourism in Rural Areas: The Case of North and Central Portugal. Journal of Travel Research 37:353-363.

Kotler, P., J. Bowen, and J. Mak

1999 Marketing for Hospitality and Tourism. Upper Saddle River NJ: Prentice Hall.

Kozak, M.

1999 Repeater's Behavior at Two Distinct Destinations. Annals of Tourism Research 28:784-807.

Laws, E.

1998 Conceptualizing Visitor Satisfaction Management in Heritage Settings: An Exploratory Blueprinting Analysis of Leeds Castle, Kent. Tourism Management 19:545-554. 
Michael, E.

2002 Antiques and Tourism in Australia. Tourism Management 23:117-125.

Morris, W.

1988 At Henry Parkes Motel. Cultural Studies 2:1-16.

Murphy, L.

2001 Exploring Social Interactions of Backpackers. Annals of Tourism Research 28(1):50-67.

Nuryanti, W.

1996 Heritage and Postmodern Tourism. Annals of Tourism Research 23: 249-260.

Palmer, C.

1999 Tourism and The Symbols of Identity. Tourism Management 20:313-322.

Peterson, R., and W. Wilson

1992 Measuring Customer Satisfaction: Fact and Artifact. Journal of The Academy of Marketing Science 20:61-71.

Poria, Y.

2001a Clarifying Heritage Tourism. Ph.D. dissertation in tourism. University of Surrey.

2001b The Show Must Not Go On. Tourism and Hospitality Research 3:115119.

2001c Challenging the Present Approach to Heritage Tourism. Tourism Review 56:51-53.

Poria, Y., R. Butler, and D. Airey

2001a Clarifying Heritage Tourism: A Comment. Annals of Tourism Research 28:1047-1049.

2001b Tourism Sub Groups: Do They Exist? Tourism Today 1:14-22.

2002 Revisiting Mieczkowski's Conceptualisation of Tourism. Tourism Geographies.

Prentice, R., S. Witt, and C. Hamer

1996 Tourism as Experience: The Case of Heritage Parks. Annals of Tourism Research 25:1-24.

Richards, G.

1996 Production and Consumption of European Cultural Tourism. Annals of Tourism Research 23:261-283.

Schiller, E.

1992 Guide to Christian Historical Sites and Holy Places in Israel (in Hebrew). Jerusalem: Arial.

Seale, R.

1996 A Perspective from Canada on Heritage and Tourism. Annals of Tourism Research 23:484-488.

Sivan, E.

1997 Arab Political Myths. Tel-Aviv: Am Oved.

Solomon, M., G. Bamossy, and S. Askegaard

1999 Consumer Behaviour: A European Perspective. Hemel Hempstead: Prentice Hall Europe.

Strauss, C., and B. Lord

2001 Economic Impacts of a Heritage Tourism System. Journal of Retailing and Consumer Services 8:199-204.

Swarbrooke, J.

1994 The Future of the Past: Heritage Tourism into the 21st Century. In Tourism the State of the Art, A. Seaton, ed., pp. 222-229. Chichester: Wiley.

1996 Understanding the Tourist: Some Thoughts on Consumer Behaviour Research in Tourism. Insights 8:A67-A76.

Teo, P., and B. Yeoh

1995 Remaking Local Heritage for Tourism. Annals of Tourism Research 24:192-213.

Timothy, D.

1997 Tourism and the Personal Heritage Experience. Annals of Tourism Research 24:751-754. 
Uriely, N., A. Israeli, and A. Reichel 2002 Heritage Proximity and Resident Attitudes towards Tourism Development. Annals of Tourism Research 29:858-862.

Urry, J.

1990 The Tourist Gaze: Leisure and Travel in Contemporary Societies. London: Sage.

Waitt, G.

2000 Consuming Heritage: Perceived Historical Authenticity. Annals of Tourism Research 27:835-862.

Yale, $\mathrm{P}$.

1997 From Tourist Attraction to Heritage Tourism. Huntingdon: ELM Publications.

Zube, E.

1987 Perceived Land Use Patterns and Landscape Values. Landscape Ecology $1: 37-45$.

Zube, E., J. Sell, and J. Taylor

1982 Landscape Perception: Research, Application and Theory. Landscape Planning 9(1):1-33.

Submitted 13 October 2001. Resubmitted 18 March 2002. Accepted 29 April 2002. Final version 3 July 2002. Refereed anonymously. Coordinating Editor: Regina G. Schlüter 